\title{
PARASITIC MYOMA IN MESENTERY MIMICKING GASTROINTESTINAL STROMAL TUMOR: A CASE OF LAPAROSCOPIC MYOMECTOMY WITH SINGLE PORT APPROACH
}

Hyo Jeong Kim, MD, Ju Hyun Ryu, MD, Tae-Joong Kim, MD, Byoung-Gie Kim, MD, PhD, Duk-Soo Bae, MD, PhD

Department of Obstetrics and Gynecology, Samsung Medical Center, Sungkyunkwan University School of Medicine, Seoul, Korea

Gastrointestinal stromal tumor (GIST) is the most common non-epithelial tumor in the gastrointestinal tract, and express a highly specific marker called c-kit (CD117). The majorinty of GISTs arise in the stomach $(60 \%)$ and small bowel $(30 \%)$, and remaining $10 \%$ in the other gastrointestinal tract. It also occurs, rarely, in non-gastrointestinal tract. We experienced a 42-year-old woman who was transferred to our hospital with the impression of GIST by positron emission tomography-computed tomography, and after the single port approach laparoscopy, finally diagnosed as parasitic myoma. Hysterectomy and complete resection of $14 \mathrm{~cm}$ sized mesenteric mass was done via single port laparoscopy. After the immunohistochemistry test, the final pathologic diagnosis was confirmed the diagnosis of myoma. We report here the case of parasitic myoma mimicking GIST with brief review of articles.

Keywords: Parasitic myoma; Gastrointestinal stromal tumors; Single-port approach

위장관 기질종양(gastrointestinal stromal tumor, GIST)는 위장관에 서 발생하는 가장 흔한 비상피성 종양이다. C-kit을 이용한 진단방법이 대두되면서 비교적 최근에 확립된 질병이며, 이전에는 평활근종과 관 련된 기질성 종양으로 분류되었던 질환이다. 위장관 기질성 종양은 위 (60\%)에서 가장 흔히 발생하며, 그 이외에도 소장, 대장, 식도 등의 위 장관에서 주로 발생하는 것으로 알려져 있으나, 드물게 위장관 이외의 장소에서도 발생하는 것으로 보고되고 있다[1-3].

자궁근종은 35세 이상의 여성에서 20-30\%에서 발견되는 흔한 자궁 의 양성종양이다. 대부분에서 무증상으로, 근종은 발생 위치에 따라 점 막하, 근층내, 장막하 자궁근종 등으로 나뉘며, 드물게 자궁 이외의 장 소에서 발견된다. 1909년 Kelly와 Cullen에 의해 이러한 이소성 근종이 처음 보고된 이후, 몇몇 증례들이 보고되어 왔다. 이소성 근종은 유경 성의 장막하 근종이 자궁과 분리되고 주변의 장기에서 새롭게 혈류 공 급을 받아 생기는 것으로 생각되고 있다. 이소성 근종은 자궁과 별개로 존재하나, 호르몬에 대한 반응은 유지되는 것으로 알려져 있다[4-8].

이소성 근종의 경우, 술 전 영상학적 검사로 정확히 진단하기 힘들 며, 이러한 경우, GIST와의 감별 또한, 크기, 위치 및 괴사 정도에 따라 다양하게 나타나 어려운 점이 있다[4,5,9].

저자들은 타 병원에서 시행한 양전자방출단층촬영(positron emission tomography, PET)상, 위장관 기질 종양이 의심되었던 42세 환자에서 싱글포트를 이용한 진단적 복강경 후, 장간막에 위치한 이소성 근종으
로 진단된 1 예를 경험하였기에 간략한 문헌 고찰과 함께 보고하는 바 이다.

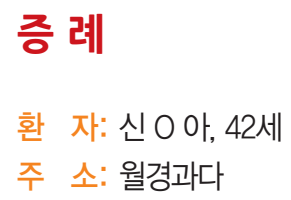

Received: 2011. 5.31. Accepted: 2011. 8. 1.

Corresponding author: Duk-Soo Bae, MD, PhD

Department of Obstetrics and Gynecology, Samsung Medical

Center, Sungkyunkwan University School of Medicine, 50 Irwon-

dong, Gangnam-gu, Seoul 135-710, Korea

Tel: +82-2-3410-3511 Fax: +82-2-3410-0630

E-mail: ds123.bae@samsung.com

This is an Open Access article distributed under the terms of the Creative Commons Attribution Non-Commercial License (http://creativecommons.org/licenses/ by-nc/3.0/) which permits unrestricted non-commercial use, distribution, and reproduction in any medium, provided the original work is properly cited.

Copyright (๑ 2011. Korean Society of Obstetrics and Gynecology 


\title{
KOREAN JOURNAL OF OBSTETRICS \& GYNECOLOGY
}

\author{
KJOG Vol. 54, No. 11, 2011
}

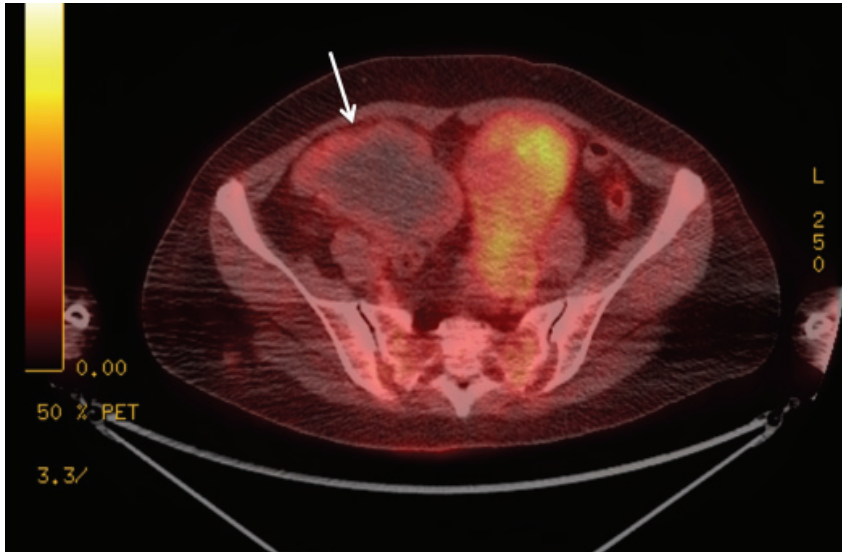

Fig. 1. Irregular shaped mass (white arrow) with central necrosis and high fludeoxyglucose uptake in the periphery is found in the right pelvic cavity and the size of tumor was about $12 \mathrm{~cm}$ in longest diameter in preoperative positron emission tomography-computed tomography scan.
산과력: 1-0-0-1

기왕력: 갑상샘 유두상 암종으로 1년전 갑상샘 전절제술 시행 후, 레보 티록신 복용 중이다.

가족력: 특이 사항 없었다.

현병력: 42세의 여자 환자는 12년전 건강검진에서 자궁근종 진단받고 정기적 추적관찰 중이었다. 타 병원에서 건강검진상 시행한 PET에서 다 발성 근종 및 GIST로 의심되는 우측 하복부 종괴가 발견되었다. 본원에 서 재판독한 결과, 다발성 근종 및 장막하 자궁근종 혹은 GIST로 생각되 어 우선 싱글포트를 이용한 시험적 복강경 및 전자궁절제술을 시행키로 결정하였다.

진찰소견: 내원 당시 혈압 $142 / 71 \mathrm{~mm} \mathrm{Hg}$, 호흡수 20회/분, 맥박수 89 회/분, 체온은 $36.2^{\circ} \mathrm{C}$ 로 정상이었다. 이학적 소견에서 안결막은 창백하 지 않았고, 공막에 황달은 없었으며, 경부 림프절 종대도 없었다. 복부는 부드럽고 진찰상 종괴가 주먹크기 이상의 크기로 하복부에서 촉지되었 다. 종괴 촉진 시 압통이나 반발통은 없었다. 간과 비장은 촉지되지 않
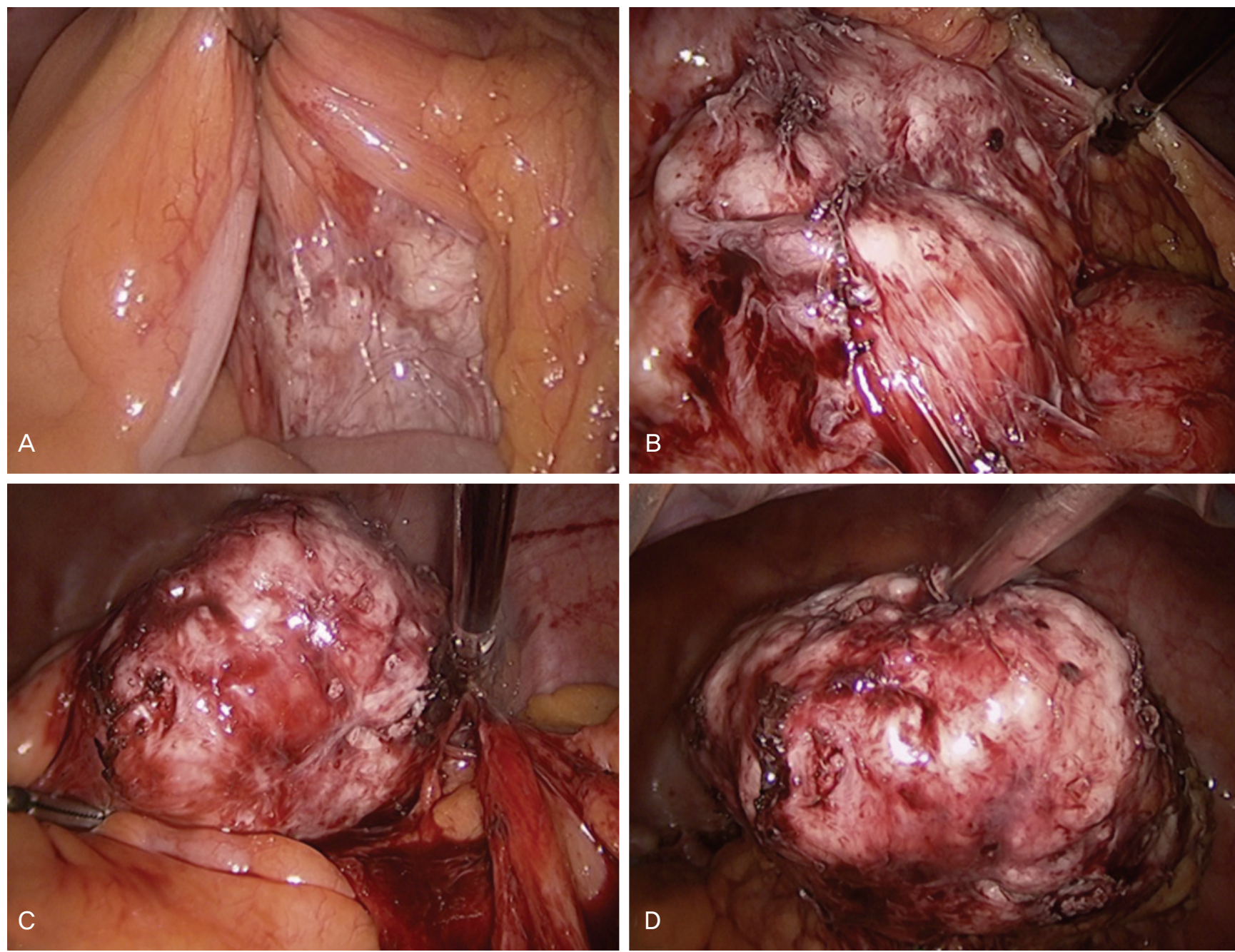

Fig. 2. Under laparoscopic evaluation, the mass is located under the mesentery of the colon and small intestines with adhesion. 


\section{KOREAN JOURNAL OF OBSTETRICS \& GYNECOLOGY}

Hyo Jeong Kim, et al. Parasitic myoma in mesentery mimicking gastrointestinal stromal tumor

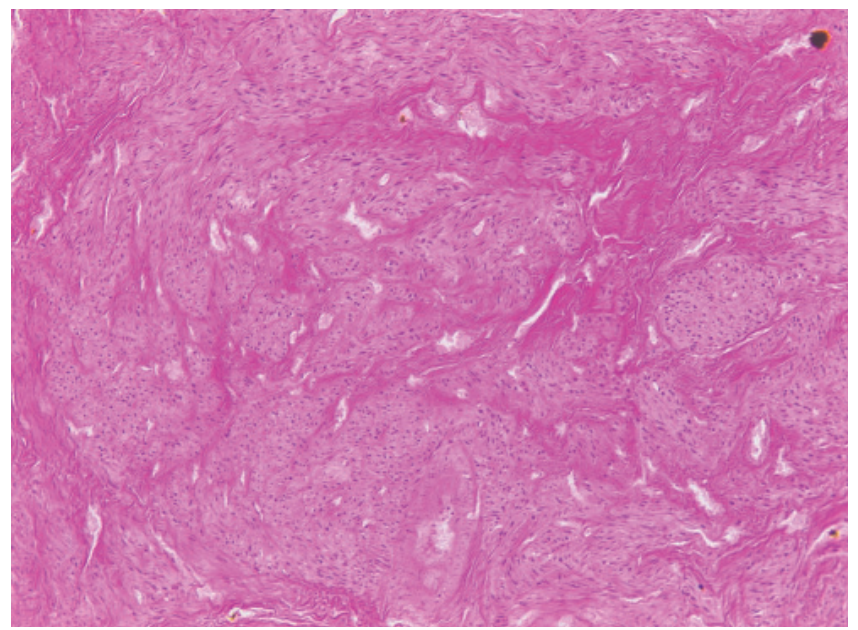

Fig. 3. The tumor is formed by interlacing bundles of smooth muscle cells with multifocal hyaline degeneration. There is no pleomorphism, atypia or excessive mitotic figures $(H \& E, \times 100)$.

았다. 골반진찰상 자궁이 성인 주먹크기 이상으로 커져 있었고, 자궁의 다발성 결절이 촉지되었다.

검사소견: 말초혈액검사, 뇨검사 및 혈청검사 모두 정상 소견이었고, 단순 흉부 $X$ 선 사진과 심전도도 정상 소견이었다. 갑상선기능검사상 thyroid stimulating hormone 0.01 외에 모두 정상 범위였다.

방사선 소견: 타 병원에서 시행한 PET상, 자궁 우측에 약 $10 \mathrm{~cm}$ 가 량의 종괴가 자궁과 일부 맞닿아 관찰되었고, 이 종괴는 주변부의 fludeoxyglucose $(\mathrm{FDG})$ 섭취 증가 및 조영 증강이 잘 되고, 중심부 괴사 를 동반하고 있었다(Fig. 1). 타 병원 판독상 GIST가 의심되었으며, 이에 대하여 본원에서 재판독을 시행한 결과, 자궁 우측의 종괴는 자궁근종 혹은 low grade GIST나 low grade sarcoma의 가능성이 있다고 판단되 었다. 다른 부위에 악성을 의심할 만한 비정상적인 FDG 섭취 증가는 보 이지 않았다.

수술 소견: 2011년 3월 29일 전신마취하에 싱글포트를 이용한 복강경 수술을 시행하였고, 자궁에 다발성 근종 및 우측 골반내에 약 $10 \mathrm{~cm}$ 가 량으로 보이는 종괴가 관찰되었다(Fig. 2). 이외에 나팔관, 난소 및 복강 내 다른 장기의 특이 소견은 보이지 않았다. 종괴는 자궁과 분리되어 존 재하였고, 대망이 종괴를 덮고 있었으며, 종괴 주변으로 대장 및 소장의 장간막이 유착되어 있었다. 수술 당시, 종괴가 자궁과 분리되어 있고 위 장관과의 연결성을 보이고 있어 GIST의 가능성을 염두에 두고, 외과의 에게 연락을 하였고, 전자궁절제술을 먼저 시행하였다. 이후, 질을 봉합 하지 않은 상태에서 식염수를 채운 장갑으로 질구를 막아, 기복강을 유 지하였다. 종괴 주변의 유착박리 시 주변 장기로의 침범은 보이지 않았 고, 장막의 손상 없이 분리되었으며, 수술장에서 외과의 의견을 구한 결 과, 종괴의 위치 및 주변 장기로의 침범이 없는 형태로, 전형적인 GIST 의 소견은 아니라고 하였다. 종괴 주변의 유착을 박리 후, 종괴를 질을 통하여 제거하였고, 수술장에 실시한 응급 동결절편검사상, 방추세포종 양으로, 동결절편상 근종 또는 GIST의 감별은 되지 않았다. 이후 복강내
를 면밀히 관찰하여 다른 부위에 종괴가 없음을 확인하였다. 병리조직검사 소견: 수술로 제거된 자궁의 무게는 $701 \mathrm{~g}$ 으로, 최대 장 경 $9 \mathrm{~cm}$ 의 다발성 자궁근종을 포함하고 있었다. 우측 골반에서 제거된 종괴는 총 $14 \times 14 \times 8 \mathrm{~cm}$ 크기의 회백색 종양으로 얇은 피막으로 경계 가 지어져 있었으며, 무게는 약 $376 \mathrm{~g}$ 이었다. 현미경 소견상 종괴는 방 추세포로 이루어져 있었고 방추세포들 사이에 유리질 변성이 관찰되었 으며, 유사분열이나 세포다형성은 관찰되지 않았다(Fig. 3). 면역조직화 학염색에서 조직세포는 smooth muscle antibody에 대하여 양성을 보였 고, c-kit에 대하여 음성으로 근종에 합당한 소견이었다[1,4].

수술 후 경과: 수술후 환자의 회복 상태는 양호하였고 합병증 없이 술 후 3일만에 퇴원하였다. 퇴원 후 외래추적 관찰상 특이 소견은 없었다.

\section{고 찰}

본 증례는 이전 골반 수술의 기왕력이 없는 환자에서 술 전 시행한 검사상 GIST 혹은 pedunculated subserosal myoma를 의심하였으나, 실제 싱글포트를 이용하여 시행한 진단적 복강경수술에서, 자궁과 분 리되어 장간막에 붙어 있는 종괴가 발견되었고, 이를 복강경을 이용하 여 성공적으로 절제한 결과, 조직병리학적 검사를 통해 근종으로 진단 되었던 증례였다. 이를 통하여 GIST 및 이소성 근종에 대한 간략한 문 헌 고찰과 감별 및 이에 대한 치료 방향을 되짚어 보고자 한다.

위장관 기질종양은 전체 위장관 종양의 $1 \%$ 미만을 차지하며, 위장 관에서 발생하는 가장 흔한 비상피성 종양으로, 카할 세포에서 기원 한 세포로 구성되며, c-kit (CD117) 발현이 높은 것이 특징이다. 이전 에는 평활근 세포로부터 기원한다고 생각되었으나, 전자현미경과 면역 화학염색검사의 발달로 카할 간질 세포가 기원임이 밝혀졌다. 진단 시 평균 연령은 60 세이며, 대부분 위(60\%)에서 발견되고, 소장 $(30 \%)$, 나 머지 $10 \%$ 는 식도, 직장 등에서 발견된다. 종양은 특징적으로 위장관 의 내강에 평행한 방향으로 돌출형 성장을 하며, 흔히 점막의 괴사와 궤양을 동반한다. 크기는 매우 다양하며, 많은 수에서 얇은 가성 피막 을 형성하고 있다. $95 \%$ 가 넘는 환자에서 단일 원발성 종양으로 발견되 며, 이중 $10-40 \%$ 가 직접적으로 주변장기를 침범한다. 위장의 GIST의 경우 위장관 출혈이나 복통을 호소할 수 있으나, 대부분의 환자는 무 증상이며, 내시경검사중 우연히 발견하게 되는 경우가 많다. 외장관 기 질종양에 대한 영상검사로는 초음파, 전산화단층촬영검사(computed tomography, CT), 자기공명영상(magnetic resonance imaging, MRI), PET 등이 이용될 수 있으나, 현재로는 CT검사가 가장 유용하게 사용되 고 있으며, 전이부위에 대한 검사를 위해서는 PET촬영이 유용하게 사 용되고 있다. 이에 대한 치료로는 절제면에서 종양세포를 남겨두지 않 는 외과적 절제가 유일하고 효과적인 치료방법으로 받이들여지고 있으 며, 림프절 전이는 매우 드물기 때문에 일반적으로 림프절절제는 시행 하지 않는다. 완전 외과적 절제를 시행하지 못한 경우 및 전이가 있는 경우에는 c-kit 수용체의 tyrosine kinase 억제제인 imatinib mesylate 치료를 시행할 수 있다[1-3]. 


\title{
KOREAN JOURNAL OF OBSTETRICS \& GYNECOLOGY
}

\author{
KJOG Vol. 54, No. 11, 2011
}

1909년, Kelly와 Cullen이 자궁과 분리되어 나타난 이소성 근종에 대 한 37건의 증례를 발표한 이후, 이와 비슷한 여러 증례들이 보고되어 왔다[4-8]. 이소성 근종의 발생 기전에 대하여는 정확히 알려진 바는 없으나, 두 가지 가설이 제시되고 있다. 첫 번째로, 원래 자궁에 연결되 어 있던 유경성의 장막하 자궁근종(pedunculated subserosal myoma) 이 자궁과 연결된 줄기부분이 염전되면서 자궁과의 연결이 분리되고, 주변장기에 연결되어 신생혈관을 생성하여 혈액공급을 받아 발생한다 는 가설이 있다[4]. 두 번째로 제시되는 가설은, morcellation을 이용한 수술 후, 복강내에 남겨진 근종의 일부가 이러한 이소성 근종이 된다는 것이다. 실제로 최근 복강경하, 혹은 개복하 자궁근종절제술과 연관된 이소성 근종의 보고가 증가되는 추세이다[6,8].

Kho와 Nezhat [5]의 12건의 이소성 근종 증례 발표에 따르면, 총 12 명의 환자 중, 11 명에서 자궁의 근종이 진단되었고, 6 명에서 이전에 morcellation을 이용한 수술의 과거력이 있었던 것으로 나타났다. 또한 2008년, 국내에서 발표된 증례에서는 이전 복강경하 근종절제술 시 사 용된 트로카 부위의 이소성 근종이 발견되기도 하였다[7].

본 증례와 같이 골반내 종괴가 자궁 및 부속기와 분리되어 존재하는 경우, 위장관 및 복막에 발생하는 종양 및 염증성 질환, 봉입낭 등에 대 한 고려가 필요하며, 드물지만 이소성 근종의 가능성이 존재하므로 골 반수술 시 복강 전반에 대한 세밀하고 주의 깊은 관찰이 필요하다.

본 증례에서는 술 전 시행한 검사상, 타 병원에서는 GIST를, 본원에 서는 장막하 자궁근종 또는 GIST의 가능성이 있다고 판단되었다. 실제 싱글포트를 이용한 진단적 복강경시행 시, 자궁과는 분리되어 장간막 에 존재하는 종괴가 발견되었고, 육안 소견 및 수술장에서 시행한 응급 동결절편검사상으로는 근종 및 GIST의 감별이 되지 않았다. 이후, 면역 조직화학염색을 통하여 근종으로 최종 진단이 확인되었다. 하지만 실 제 종양이 GIST라고 하더라도, 수술 시 림프절절제 등 추가 수술이 필 요하지는 않고, 완전한 절제가 되지 않거나, 전이가 있는 경우에서만 술 후 추가 치료를 하는 것으로 알려져 있어 치료방향에는 영향을 주지 않았다.

저자들은 본 증례를 통하여, 산부인과에서 흔히 접하게 되는 골반내 종괴에 대한 감별에 있어, 흔하지는 않으나, 육안 소견이나 동결절편검 사상 감별하기 쉽지 않아 진단에 어려움이 있는 이소성 근종과 GIST를
고려해볼 필요가 있음을 제시하고자 한다.

\section{References}

1. Machairas A, Karamitopoulou E, Tsapralis D, Karatzas T, Machairas N, Misiakos EP. Gastrointestinal stromal tumors (GISTs): an updated experience. Dig Dis Sci 2010;55:3315-27.

2. Kang YK, Kim KM, Sohn T, Choi D, Kang HJ, Ryu MH, et al. Clinical practice guideline for accurate diagnosis and effective treatment of gastrointestinal stromal tumor in Korea. J Korean Med Sci 2010;25:1543-52.

3. Blay JY, von Mehren M, Blackstein ME. Perspective on updated treatment guidelines for patients with gastrointestinal stromal tumors. Cancer 2010;116:5126-37.

4. Fasih N, Prasad Shanbhogue AK, Macdonald DB, Fraser-Hill MA, Papadatos D, Kielar AZ, et al. Leiomyomas beyond the uterus: unusual locations, rare manifestations. Radiographics 2008;28:1931-48.

5. Kho KA, Nezhat C. Parasitic myomas. Obstet Gynecol 2009;114:611-5.

6. Larraín D, Rabischong B, Khoo CK, Botchorishvili R, Canis M, Mage G. "latrogenic" parasitic myomas: unusual late complication of laparoscopic morcellation procedures. J Minim Invasive Gynecol 2010;17:719-24.

7. Moon HS, Koo JS, Park SH, Park GS, Choi JG, Kim SG. Parasitic leiomyoma in the abdominal wall after laparoscopic myomectomy. Fertil Steril 2008:90:1201.e1-2.

8. Nezhat C, Kho K. latrogenic myomas: new class of myomas? J Minim Invasive Gynecol 2010;17:544-50.

9. Yeh HC, Kaplan M, Deligdisch L. Parasitic and pedunculated leiomyomas: ultrasonographic features. J Ultrasound Med 1999;18:789-94. 


\section{KOREAN JOURNAL OF OBSTETRICS \& GYNECOLOGY}

Hyo Jeong Kim, et al. Parasitic myoma in mesentery mimicking gastrointestinal stromal tumor

\section{위장관 기질종양으로 오인된 장간막의 이소성 평활근종: 싱글포트 복강경을 이용한 근종절제술 시행의 1예}

\section{성균관대학교 의과대학 삼성서울병원 산부인과}

김효정, 류주현, 김태중, 김병기, 배덕수

위장관 기질종양은 위장관의 비상피성 종양 중 가장 흔한 종양이다. c-kit를 이용한 진단방법으로 비교적 최근에 확립된 질병이며, 이전 에는 평활근종과 관련된 기질성 종양으로 분류되었던 질환이다. 위장관 기질성 종양은 대부분 위(60\%)에서 발견되고, 소장(30\%), 대장, 식 도 등의 위장관에서 주로 발생하는 것으로 알려져 있으나, 드물게 위장관 이외의 장소에서도 발생하는 것으로 보고되고 있다. 저자들은 타 병원에서 실시한 positron emission tomography상 위장관 기질종양으로 진단 받은 42세 여자 환자에게서, 싱글포트를 이용한 진단적 복강 경을 시행, 수술 후 면역조직화학염색을 통하여 자궁외에 위치한 이소성 근종으로 진단된 증례를 경험하였다. 이에 대하여 GIST와 이소성 근종의 감별 및 치료방향에 대하여 간략한 문헌 고찰과 함께 보고하는 바이다.

중심단어: 이소성 근종, 위장관 기질종양, 싱글포트 